\title{
The Effectiveness of Children YouTube Songs and Flashcard Games to Teach Vocabulary to Kindergarten Pupils
}

\author{
Gabriella Anindyarizki Widhiprasetya $^{1 凶}$,Januarius Mujiyanto $^{2}$, Djoko Sutopo $^{2}$ \\ 1. Karangturi School Semarang, Indonesia \\ 2. Universitas Negeri Semarang, Indonesia
}

\begin{abstract}
Article Info
Article History:

Article History:

Recived 28 July 2021

Accepted 3 October

2021

Published 23

December 2021

Keywords:

Effectiveness, Teach

Vocabulary,

Kindergarten Pupils.

Abstract

Teaching English to young learners has attracted many people in the last decades worldwide, so that English has been increasingly practised at the kindergarten levels. The role of parents is very crucial in the early stage of a child. This research shows the effective interaction between kindergarten children's YouTube songs, flashcard games, and parental involvement in vocabulary learning at Kindergarten Karangturi with online teaching. This research was a quasi-experimental study with a $2 \times 2$ factorial design that focuses on two or more independent variables or factors on at least one dependent variable. This study employed two independent variables: teaching with YouTube songs and flashcard games based on the design. This study reveals that there was no significant interaction between two teaching media in teaching vocabulary and parent's involvement. Using YouTube songs and flashcard games as the vocabulary teaching media to pupils with high parent involvement was effective. However, it also reveals that using youtube songs and flashcard games was ineffective as the vocabulary teaching media to pupils with low parent involvement. This study shows no significant difference in teaching vocabulary with YouTube songs compared with flashcard games to Karangturi Kindergarten pupils. Further research was expected to continue this study by finding another method to teach young learners English to enhance their language mastery.
\end{abstract}




\section{INTRODUCTION}

English has become one of the important global languages of communication and, in recent years, it has expanded throughout the world. Due to its importance, English has become the most widely taught language in our schools. Teaching English to young learners has also attracted many people in the last decades; therefore, English education has been increasingly practised at the kindergarten levels. English is considered a foreign language in Indonesia, and it is trendy. It is taught at all levels of educations stages. For many years, teaching a foreign language to kindergarten children was seen as something additional to the standard curriculum in the school system. Progressively, educators have come to recognize the importance of starting foreign language learning at an early age. Learning is among everyday experiences to everyone, but it is most apparent for young learners who rapidly acquire new behaviours, facts, languages, ideas, and concepts (Bartsch, Horvath, \& Estes, 2003). Most of the kindergarten school in Indonesia has English subject as one of the essential subjects that need to be taught every day.

One of the English components that have to be taught to pupils is vocabulary. It plays an essential part in language skills; listening, speaking, reading, and writing. Vocabulary is also one of the essential elements in the language. It is an essential component of language and a crucial component in requiring and understanding language. We cannot speak well if we do not master it.

One of the objectives in teaching English to Indonesian people is to enable pupils to read and understand a book in written English and communicate in English. To achieve that purpose, the pupils need many words of the English language to master. As Schmitt (1997) said, no matter how well the pupils learn grammar, no matter how successfully the sounds of L2 are mastered, without words to express a broader range of meaning, communication in an L2 cannot happen in any meaningful way. From this statement, it could be understood that vocabulary is one of the items that have to be mastered by the pupils in learning English because no one can speak English if they have limited vocabulary. In other words, without a proportional amount of vocabulary, anyone will get trouble in his or her reading, listening, speaking, and writing. According to Maera (1996), Lexical competence is at the heart of communication competence. In other words, vocabulary is essential for communication; without good vocabulary knowledge, communication could not simply occur.

Therefore, considering the young learners' characteristics and also language instruction are of utmost importance. Young learners tend to learn language more implicitly rather than explicitly (Pinter, 2006). Even though the language learning experience is something exciting and attractive for some learners, for some others, it is a tiresome activity that makes them wish to get away from it.

Teaching English to young learners will be very completely different from teaching English to adults. Young learners are unique. They are different from adults with very different needs, interests, and abilities and are more enthusiastic than adults in language activity. Many parents believe that their kindergarten children will get a better future by studying English early, so the Indonesia Ministry of Education has begun to respond by introducing English as a foreign language in elementary school, even in kindergarten. Using games will make pupils have more excitement in learning a language. It will help the teacher to decrease the bored level of the pupils in learning a new language. Using songs is one of the remarkable ways to introduce English vocabulary to young learners. The learners, the parents, and the teachers can get many benefits from this method. Moreover, kids now are very familiar with YouTube. It is a video-sharing internet website that all ages can be accessed on PCs, laptops, tablets, or mobile phones.

Parenting is a crucial component of students' success. According to (Harris, 2014), Parent involvement can broadly be defined as how parents support their kindergarten children's education in word and act. Parents can either be 
involved in the school setting or at home; their aspirations and expectations for their kindergarten children also matter very much. Parents get involved because they develop a personal construction of the parental role that included participation in their kindergarten children's education; they develop a positive sense of helping their kindergarten children succeed in school. On average, kids spend their time at school around 3-5 hours a day and spend the rest of their time at home or with their family. So the role of parents is crucial to the improvement of their kids' education achievement.

Covid 19 has currently colonized Indonesia, where the spread of the disease is swift. Not only in Indonesia, but all corners of the world are currently experiencing a health crisis. Initially, the spread of Covid 19 had an impact on economic activity, which began to decline; not only It was reported from the Kompas daily (2020) that the government in several regions also made policies road closure to territorial restrictions for residents who want to enter and exit in a specific area which is also called lockdown. However, currently, the impact of the outbreak is also being felt by the education World. The United Nations or the United Nations states that one of the affected sectors is this epidemic is the world of education (Purwanto et al., 2020). It makes several countries decided to close both schools and colleges. To prevent the spread of covid 19, the World Health Organization (WHO) recommends stopping while activities that would potentially create a crowd. Even during the outbreak, covid 19 in Indonesia, there are many ways that the government has taken to prevent it spread by social distancing, one of which is the existence of a Ministry Circular Education and Culture (Kemendikbud) Directorate of Higher Education No. 1 of 2020 regarding the prevention of the spread of covid 19 in the world of education. In this circular, Kemendikbud instructed to organize distance learning and suggested the students learn from their homes.

Covid 19 on teaching and learning activities has been quite noticeable; It can be seen from learning that is supposed to be done directly and consciously can only be done independently. Students do indirect learning by utilizing online or online learning deemed quite effective in situations like this. The impact of this covid 19 outbreak has not subsided; learning will continue to be carried out from each house (study from home). One alternative so that learning continues, namely with online learning. Moore et al. in Firman and Sari (2020) mentioned that online learning is a learning activity that requires an Internet network with connectivity, accessibility, flexibility, and the ability to raises various types of learning interactions. (Zhang et al., 2004) show that the internet and multimedia technology can change the delivery of knowledge and can be an alternative to learning implemented in class. Implementation of online learning requires smartphones, laptops, or tablets to access information wherever and whenever (Gikas \& Grant, 2013). In Indonesia, there are several applications provided by the government to support learning activities at home. Apart from that, educators can faceto-face with their students through an accessible application with an internet network. However, some of the obstacles in online learning create students who are less interested in online learning.

\section{METHODS}

This research was a quasi-experimental study with a $2 \times 2$ factorial design that focuses on two or more independent variables or factors on at least one dependent variable. This study employed two independent variables: teaching with YouTube songs and flashcard games based on the design. There is one dependent variable, 
which is teaching vocabulary. Since this study attempted to compare two independent variables, teaching with YouTube songs and teaching with flashcard games, this study uses two experimental groups. The first experimental class will teach using YouTube songs, and the second experimental class will be taught with flashcard games.

\section{RESULTS AND DISCUSSIONS}

In order to measure the data, the researcher used Analysis of Variance (ANOVA) to know the results of the hypotheses.

Hypothesis 1: There is a significant interaction between two teaching media in teaching vocabulary and parent's involvement

Dependent variable: the results of the pre-test and post-test of the vocabulary test on pupils in the $1^{\text {st }}$ and $2^{\text {nd }}$ experimental class

Table 1. A 2-way ANOVA for H1

\begin{tabular}{|lccrrr|}
\hline Source & SS & Df & \multicolumn{1}{c}{ MS } & \multicolumn{1}{c|}{ F } & Sig. \\
\hline Corrected Model & & 7 & 669.154 & 25.265 & .000 \\
\hline Intercept & $4684.075 a$ & & & & \\
\hline Teaching Media & 16129.18 & 1 & 16129.18 & 608.99 & .000 \\
\hline $\begin{array}{l}\text { Parent's } \\
\text { Involvement }\end{array}$ & 506.097 & 2 & 253.049 & 9.554 & .000 \\
\hline $\begin{array}{l}\text { Teaching Media*Parent's } \\
\text { Involvement }\end{array}$ & 701.232 & 2 & 350.616 & 13.238 & .000 \\
\hline Error & 307.128 & 3 & 102.376 & 3.865 & .011 \\
\hline Total & 3972.766 & 150 & 26.485 & & \\
\hline Corrected Total & 78545 & 158 & & & \\
\hline & 8656.842 & 157 & & & \\
\hline
\end{tabular}

a. $\mathrm{R}$ squared $=.541($ Adjusted $\mathrm{R}$ squared $=.520)$

The results of the analysis of variance (ANOVA) are shown in Table 8 below. Table 8 shows a means squares (F) ratio of 3.865 and a significance level ( $\mathrm{Sig}$ ) of .011 or less than .05 for the first-order interaction of teaching media and parent involvement. The ANOVA clearly showed an interaction between these two independent variables regarding the pre-test and post-test results of the vocabulary test.

A 2-way ANOVA was conducted to show the interaction between two teaching media in teaching vocabulary and parent's involvement in the $1^{\text {st }}$ and $2^{\text {nd }}$ experimental classes. Teaching media in teaching vocabulary included (YouTube songs and flashcard games) and parent's involvement included three levels (low, moderate, and high). The analysis results indicated there was a statistically significant difference for the main effect of teaching media. It was a ratio of means squares $(F)$ of 9.554 and a significance level ( $\mathrm{Sig}$ ) of .000 for the main effect of teaching media and, a ratio of means squares $(F)$ of 13.238 and a significance level ( $\mathrm{Sig}$ ) of .000 for the main effect of parent's involvement. The interaction between two teaching media in teaching vocabulary and parent's involvement in the $1^{\text {st }}$ and $2^{\text {nd }}$ experimental class was a means squares $(F)$ of 3.865 and a significance level (Sig) of .011 or less than .05 . However, there was no statistically significant difference in the interaction effect.

Hypothesis 2: Using YouTube songs as the vocabulary teaching media to pupils with high parent involvement is effective.

Dependent variable: the results of the pretest and post-test of the vocabulary test on pupils with high parents' involvement in the $1^{\text {st }}$ experimental class

Table 2. A 2-way ANOVA for $\mathrm{H} 2$

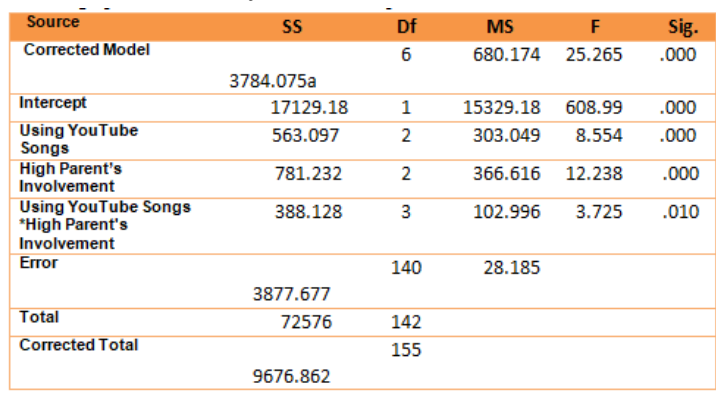

a. $\mathrm{R}$ squared $=.421$ (Adjusted R squared $=.415)$

The analysis result of variance (ANOVA) clearly showed that it was effective to use YouTube songs as the vocabulary teaching media to pupils with high parents involvement, and there was the interaction between using YouTube songs as the vocabulary teaching media and high parents involvement as two independent variables concerning the results of the pre-test and post-test of the vocabulary test.

A 2-way ANOVA indicated there was a statistically significant difference for the main effect of teaching media. It was a ratio of means squares $(F)$ of 8.554 and a significance level ( $\mathrm{Sig}$ ) 
of .000 for the main effect using youtube songs and, a ratio of means squares $(F)$ of 12.238 , and a significance level (Sig) of .000 for the main effect high parent's involvement. The interaction between using YouTube songs as the vocabulary teaching media and high parent's involvement as two independent variables concerning the pre-test and post-test results of the vocabulary was a ratio of means squares $(\mathrm{F})$ of 3.725 and a significance level (Sig) of Sig .010 or less than .05. However, there was no statistically significant difference for the interaction effect, and it was effective to use YouTube songs as the vocabulary teaching media to pupils with high parent involvement.

Hypothesis 3: Using YouTube songs as the vocabulary teaching media to pupils with low parent involvement is effective. Dependent variable: the results of the pre-test and post-test of the vocabulary test on pupils with low parents' involvement in $1^{\text {st }}$ experimental class

Table 3. A 2-way ANOVA for $\mathrm{H} 3$

\begin{tabular}{|c|c|c|c|c|c|}
\hline Source & SS & Df & MS & $\mathrm{F}$ & Sig. \\
\hline \multirow[t]{2}{*}{ Corrected Model } & & 1 & 1084.330 & 106.275 & .348 \\
\hline & 84.330 & & & & \\
\hline Intercept & 17129.18 & 1 & 1084.330 & 140,188 & .000 \\
\hline $\begin{array}{l}\text { Using YouTube } \\
\text { Songs }\end{array}$ & .150 & 1 & .150 & .015 & .000 \\
\hline $\begin{array}{l}\text { Low Parent's } \\
\text { Involvement }\end{array}$ & 3.507 & 1 & 3.507 & .344 & .002 \\
\hline $\begin{array}{l}\text { Using YouTube Songs * } \\
\text { Low Parent's } \\
\text { Involvement }\end{array}$ & 4.909 & 1 & 4.909 & .489 & .002 \\
\hline Error & & 199 & 10.203 & & \\
\hline & 2030.416 & & & & \\
\hline Total & 3227.000 & 204 & & & \\
\hline Corrected Total & & 203 & & & \\
\hline & 3142.877 & & & & \\
\hline
\end{tabular}

a. R Squared - .354 (Adjusted R Squared- .341)

The results of the analysis of variance (ANOVA) clearly showed that it was not effective to use YouTube songs as the vocabulary teaching media to pupils with low parent's involvement, and there was statistically no interaction between using YouTube songs as the vocabulary teaching media and low parent's involvement as two independent variables concerning the results of the pre-test and post-test of the vocabulary test.

A 2-way ANOVA indicated that the use of YouTube songs as the vocabulary teaching media to pupils with low parent's involvement use YouTube songs as the vocabulary teaching media to pupils with low parents' involvement did not have a significant effect on the pupils' results of the pre-test and post-test of the vocabulary test. It was a ratio of means squares $(F)$ of .015 and a significance level ( $\mathrm{Sig}$ ) of .000 for the main effect using youtube songs and, a ratio of means squares $(F)$ of .344 and a significance level ( $\mathrm{Sig}$ ) of .002 for the primary effect parent's involvement. The interaction between using YouTube songs as the vocabulary teaching media and low parent's involvement as two independent variables concerning the results of the pre-test and post-test of the vocabulary test was a ratio of means squares $(F)$ of .489and a significance level ( $\mathrm{Sig}$ ) of .002 or more than .05 . However, there was a statistically significant difference for the interaction effect, and it was not effective to use YouTube songs as the vocabulary teaching media to pupils with low parent involvement.

Hypothesis 4: It is effective to use flashcard games to teach vocabulary to pupils with high parent involvement.

Dependent variable: the results of the pretest and post-test of the vocabulary test on pupils with high parents' involvement in $2^{\text {nd }}$ experimental class

Table 4. A 2-way ANOVA for $\mathrm{H} 4$

\begin{tabular}{|lccrrr|}
\hline Source & SS & Df & \multicolumn{1}{c}{ MS } & \multicolumn{1}{c}{ F } & Sig. \\
\hline Corrected Model & $2784.075 a$ & 6 & 550.124 & 21.205 & .000 \\
\hline $\begin{array}{l}\text { Intercept } \\
\text { Using Flashcard }\end{array}$ & 653.097 & 2 & 355.049 & 7.004 & .000 \\
$\begin{array}{l}\text { Games } \\
\text { High Parent's } \\
\text { Involvement }\end{array}$ & 661.232 & 2 & 398.616 & 11.238 & .000 \\
\hline $\begin{array}{l}\text { Teaching Media*Low } \\
\text { Parent's Involvement }\end{array}$ & 208.128 & 3 & 89.996 & 2.725 & .008 \\
\hline Error & 3599.677 & 140 & 20.185 & & \\
\hline Total & 66576 & 142 & & & \\
\hline Corrected Total & 8236.862 & 155 & & & \\
\hline
\end{tabular}

a. $\mathrm{R}$ squared $=.401$ (Adjusted $\mathrm{R}$ squared $=.408)$

The results of the analysis of variance (ANOVA) clearly showed that it was effective to use flashcard games as the vocabulary teaching media to pupils with high parent's involvement, and there was an interaction between using flashcard games as the vocabulary teaching media and high parent's involvement as two independent variables concerning the results of the pre-test and post-test of the vocabulary test.

A 2-way ANOVA indicated there was a statistically significant difference for the main effect of teaching media. It was a ratio of means squares $(F)$ of 7.004and a significance level (Sig) 
of .000 for the main effect using flashcard games and, a ratio of means squares $(F) 11.238$ and a significance level ( $\mathrm{Sig}$ ) of .000 for the main effect high parent's involvement. The interaction between using flashcard games as the vocabulary teaching media and high parent's involvement as two independent variables concerning the results of the pre-test and post-test of the vocabulary test was a ratio of means squares $(F)$ of 2.725 and a significance level ( $\mathrm{Sig}$ ) of .008 or less than .05. However, there was no statistically significant difference for the interaction effect, and it was effective to use flashcard games as the vocabulary teaching media to pupils with high parent involvement.

4.3.5 Hypothesis 5: It is effective to use flashcard games as the vocabulary teaching media to pupils with low parent involvement.

Dependent variable: the results of the pretest and post-test of the vocabulary test on pupils with low parents' involvement in $2^{\text {nd }}$ experimental class

Table 5. A 2-way ANOVA for H5

\begin{tabular}{|lccrrr|}
\hline Source & SS & Df & \multicolumn{1}{c}{ MS } & \multicolumn{1}{c|}{ F } & Sig. \\
\hline Corrected Model & 1174.330 & 1 & 1174.330 & 136.255 & .348 \\
\hline $\begin{array}{l}\text { Intercept } \\
\text { Using Flashcard }\end{array}$ & 17129.18 & 1 & 1174.330 & 144,188 & .000 \\
\hline $\begin{array}{l}\text { Games } \\
\text { Low Parent's }\end{array}$ & .170 & 1 & .172 & .023 & .000 \\
\hline $\begin{array}{l}\text { Involvement } \\
\text { Peaching Media* Low } \\
\text { Parent's Involvement }\end{array}$ & 4.507 & 1 & 4.507 & .365 & .003 \\
\hline Error & 5.209 & 1 & 5.209 & .489 & .003 \\
\hline Total & 2000.416 & 199 & 11.223 & & \\
\hline Corrected Total & 3258.000 & 204 & & & \\
\hline
\end{tabular}

a. R Squared - .333 (Adjusted R Squared- .340)

The results of the analysis of variance (ANOVA) clearly showed that it was not effective to use flashcard games as the vocabulary teaching media to pupils with low parent's involvement, and there was statistically no interaction between using flashcard games as the vocabulary teaching media and low parent's involvement as two independent variables concerning the results of the pre-test and post-test of the vocabulary test.

A 2-way ANOVA indicated that the use of flashcard games as the vocabulary teaching media to pupils with low parent's involvement use flashcard games as the vocabulary teaching media to pupils with low parent's involvement did not have a significant effect on the pupils' results of the pre-test and post-test of the vocabulary test. It was a ratio of eans squares $(F)$ of .023 and a significance level ( $\mathrm{Sig}$ ) of .000 for the main effect using flashcard games and, a ratio of means squares $(F)$ of .365and a significance level (Sig) of .003 for the main effect low parent's involvement. The interaction between using flashcard games as the vocabulary teaching media and low parent's involvement as two independent variables concerning the results of the vocabulary tests (pre-test and post-test) was a ratio of means squares $(F)$ of .489 and a significance level (Sig) of .003 or more than .05. However, there was a statistically significant difference for the interaction effect, and it was not effective to use flashcard games as the vocabulary teaching media to pupils with low parent involvement.

a. Hypothesis 6: Using YouTube songs and flashcard games as the vocabulary teaching media to pupils with high parent involvement is effective.

Dependent variable: the post-test results of the vocabulary test on pupils with high parents' involvement in $1^{\text {st }}$ and $2^{\text {nd }}$ experimental class.

Table 6. A 3-way ANOVA for H6

\begin{tabular}{|c|c|c|c|c|c|}
\hline Source & ss & Df & MS & $\mathrm{F}$ & Sig. \\
\hline Corrected Model & $4181.005 a$ & 6 & 680.174 & 25.265 & .000 \\
\hline Intercept & 14729.18 & 1 & 15329.18 & 608.99 & .000 \\
\hline $\begin{array}{l}\text { Using YouTube } \\
\text { Songs }\end{array}$ & 463.097 & 1 & 303.049 & 8.554 & .000 \\
\hline $\begin{array}{l}\text { Using Flashcard } \\
\text { Games }\end{array}$ & 681.232 & 1 & 366.616 & 12.238 & .000 \\
\hline High Parents'Involvement & 388.128 & 3 & 102.996 & 3.725 & .004 \\
\hline $\begin{array}{l}\text { Using You Tube Songs*Using } \\
\text { Flashcard games" } \text { High Parents' }_{\text {involvement }}\end{array}$ & 354.765 & 3 & 28.185 & 3.644 & .004 \\
\hline Error & 3877.677 & 142 & & & \\
\hline Total & 72576 & 155 & & & \\
\hline Corrected Total & 9676.862 & 143 & & & \\
\hline
\end{tabular}

a. $\mathrm{R}$ squared $=.501$ (Adjusted $\mathrm{R}$ squared $=.555)$

The results of the analysis of variance (ANOVA) revealed that it was effective to use youtube songs and flashcard games as the vocabulary teaching media to pupils with high parent's involvement, and there was statistically an interaction between using youtube songs and 
flashcard games as the vocabulary teaching media and high parent's involvement as three independent variables concerning the pupils' results of the post-test of the vocabulary test.

The 3-way analysis of variance results showed significant 3-way interaction between the variables on the pre-test and post-test vocabulary tests. Table 1 shows an $F$ ratio of 3.644 and a significance of .004 for the interaction and the effect of youtube songs, flashcard games, and high parent involvement concerning the pupils' post-test results of the vocabulary test. However, there was no statistically significant difference for the interaction effect, and it was effective to use youtube songs flashcard games as the vocabulary teaching media to pupils with high parent involvement.

Hypothesis 7: Using YouTube songs and flashcard games as the vocabulary teaching media to pupils with low parent involvement is effective. Dependent variable: the results of the post-test of the vocabulary test on pupils with low parents' involvement in $1^{\text {st }}$ and $2^{\text {nd }}$ experimental class

Table 7. A 3-way ANOVA for H7

\begin{tabular}{|c|c|c|c|c|c|}
\hline Source & ss & Df & MS & $\mathrm{F}$ & Sig. \\
\hline Corrected Model & 4817.005a & 13 & 380.174 & 13.265 & .000 \\
\hline Intercept & 12929.182 & 1 & 12329.18 & 508.99 & .000 \\
\hline $\begin{array}{l}\text { Using YouTube } \\
\text { Songs }\end{array}$ & 163.097 & 2 & 69.049 & 2.554 & .076 \\
\hline $\begin{array}{l}\text { Using Flashcard } \\
\text { Games }\end{array}$ & 577.432 & 2 & 266.716 & 10.751 & .000 \\
\hline Low Parents'Involvement & 2.128 & 1 & 2.128 & .100 & .752 \\
\hline $\begin{array}{l}\text { Using YouTube Songs* Using } \\
\text { Flashcard games* Low Parents' } \\
\text { involvement }\end{array}$ & 34.765 & 1 & 34.765 & 1.644 & .282 \\
\hline Error & 3877.677 & 145 & & & \\
\hline Total & 72576 & 156 & & & \\
\hline Corrected Total & 9176.862 & 153 & & & \\
\hline
\end{tabular}

a. R Squared $=.556($ Adjusted $\mathrm{R}$ Squared $=.516)$

The results of the analysis of variance (ANOVA) told us that it was not effective to use youtube songs and flashcard games as the vocabulary teaching media to pupils with low parent's involvement, and there was not a statistical interaction between using youtube songs and flashcards games as the vocabulary teaching media and low parent's involvement as three independent variables concerning the pupils' results of the post-test of the vocabulary test.

The results of the 3-way analysis of variance showed no significant 3-way interaction between the variables on the results of the vocabulary tests (pre-test and post-test). Table 1 shows an $\mathrm{F}$ ratio of 1.644 and a significance of .282 for the interaction and the effect of youtube songs, flashcard games, and low parent involvement concerning the pupils' post-test results of the vocabulary test. However, there was a statistically significant difference for the interaction effect, and it was not effective to use youtube songs flashcard games as the vocabulary teaching media to pupils with low parent involvement.

Hypothesis 8: There is a significant difference in teaching vocabulary with YouTube songs compared with flashcard games to Karangturi Kindergarten pupils.

Dependent variable: the results of the posttest of the vocabulary test on pupils in 1 st and 2 nd experimental class

Table. 8 A 2-way ANOVA for $\mathrm{H} 2$

\begin{tabular}{|c|c|c|c|c|c|}
\hline Source & SS & Df & MS & $\mathrm{F}$ & Sig. \\
\hline \multirow[t]{2}{*}{ Corrected Model } & & 5 & 510.164 & 19.905 & .000 \\
\hline & $24.025 a$ & & & & \\
\hline Intercept & 15769.18 & 2 & 19829.18 & 598.88 & .000 \\
\hline $\begin{array}{l}\text { Using Youtube } \\
\text { Songs }\end{array}$ & 553.097 & 2 & 355.049 & 2.604 & .001 \\
\hline $\begin{array}{l}\text { Using Flashcard } \\
\text { Games }\end{array}$ & 661.232 & 1 & 298.616 & 2.738 & .001 \\
\hline $\begin{array}{l}\text { Using You tube Songs }{ }^{*} \\
\text { Using Flashcard Games }\end{array}$ & 208.128 & 1 & 69.996 & 2.725 & .001 \\
\hline Error & & 140 & 20.185 & & \\
\hline & 2599.677 & & & & \\
\hline Total & 56576 & 142 & & & \\
\hline Corrected Total & & 155 & & & \\
\hline & 8136.862 & & & & \\
\hline
\end{tabular}

a. $\mathrm{R}$ squared $=.574$ (Adjusted $\mathrm{R}$ squared $=.572)$

The results of $A$ 2-way ANOVA showed no significant difference in teaching vocabulary with YouTube songs compared with flashcard games to Karangturi Kindergarten pupils. It was a ratio of eans squares $(F)$ of 2.604 and a significance level ( $\mathrm{Sig}$ ) of .001 for the main effect using youtube songs and, a ratio of means squares $(F)$ of 2.738, and a significance level ( $\mathrm{Sig}$ ) of .001 for the main effect using flashcard games and it represented the miniature effect. The same is observed between using youtube songs and flashcard games where a ratio of means squares $(F)$ of 2.725 and a significance level ( $\mathrm{Sig}$ ) of .001 . It represented a small effect, but there was no significant difference in teaching vocabulary with YouTube songs compared with flashcard games 
to Karangturi Kindergarten pupils in the 1st and 2nd experimental classes.

The analysis of variance (ANOVA) in $\mathrm{H} 1$ has shown no statistically significant difference in the interaction effect between two teaching media in teaching vocabulary and parent involvement in the $1^{\text {st }}$ and $2^{\text {nd }}$ experimental classes.

In $\mathrm{H} 2$, the analysis of variance (ANOVA) revealed no statistically significant difference for the interaction effect, and it was effective to use YouTube songs as the vocabulary teaching media to pupils with high parent involvement.

In $\mathrm{H} 3$, the researcher pointed out a statistically significant difference for the interaction effect, and it was not effective to use YouTube songs as the vocabulary teaching media to pupils with low parent involvement.

In $\mathrm{H} 4$, the researcher showed no statistically significant difference for the interaction effect, and it was effective to use flashcard games as the vocabulary teaching media to pupils with high parent involvement.

In $\mathrm{H} 5$, the analysis of variance (ANOVA) showed a statistically significant difference for the interaction effect, and it was not effective to use flashcard games as the vocabulary teaching media to pupils with low parent involvement.

In H6, the researcher showed no statistically significant difference for the interaction effect, and it was effective to use youtube songs flashcard games as the vocabulary teaching media to pupils with high parent involvement.

In $\mathrm{H} 7$, the researcher showed a statistically significant difference in the interaction effect, and it was not effective to use youtube songs flashcard games as the vocabulary teaching media to pupils with high parent involvement.

In $\mathrm{H} 8$, variance (ANOVA) analysis has revealed no significant difference in teaching vocabulary with YouTube songs compared with flashcard games to Karangturi Kindergarten pupils in the $1^{\text {st }}$ and $2^{\text {nd }}$ experimental class.

These findings are approved by studies on involving the parents in teaching the English vocabulary process. One of the studies is by Walberg (2011), who states that parental behaviours impact children. Children whose parents are highly involved in their learning process could perform better in school, such as getting better grades, getting a higher score on standardized tests, dropping out less often. Their attendance records were reported to have good records, higher aspirations, and more positive attitudes about school and homework.

In addition, these findings are approved by Henderson and Redding (2011), who postulate that parents should be active in participating in the training program that the school arranges to increase their involvement in their children's education. Flecha (2012) said this type of involvement is educative participation. Moreover, recently, children often follow what people in the community do rather than what their parents and teachers instructed. Therefore, it is essential for parents and schools to actively socialize with the community to effectively gain their children's education. Flecha (2012) suggests that decisive participation can be done by letting families become representatives in the school's decision-making bodies. Schneider, Avis, and Leighton (2007) say that parents have a strong voice in determining what services are advance in the educational institution. This is an important matter since the appropriate consideration of passing policy will also influence the children's education. It is also in line with Sonntag (2014), who suggests that parents should understand their children's academic year well, as Lunts (2003) notes that two-way school-family communication is a factor that influences parental involvement. Sheldon (2011) points out that schools can inform and determine the suitable program in the school by admitting and addressing the challenges families face.

The present study has the same line as Harmer's (2001) study. He points out the variety of media that can explain language meaning and engage students in a topic, including pictures, images, overhead projector, board, bits and pieces (natural things), and language laboratory. This present study revealed no significant d0069fference in teaching vocabulary with YouTube songs compared with flashcard games to Karangturi Kindergarten pupils in the $1^{\text {st }}$ and $2^{\text {nd }}$ experimental class. 
The findings of this study are propped by Murphy (1992) and Rouse (2005) in their study about teaching vocabulary by using YouTube and songs. Murphy (1992) mentions that young children are generally ideal students in using songs as they accept almost any kind of music, especially when allowed and encouraged to move. They can listen to the same song many times without getting bored, which is good because of the repetition. There is a higher possibility that a child will remember the song. It is natural for children to sing songs and move in the rhythm of the music, they feel eased, and their interest is unforced. Another especially crucial thing is that young children are not so shy. They are not afraid to sing aloud and easily express their feelings. Murphey (1992, p.127) overemphasizes, "no matter how enjoyable or memorable, singing songs in it will not teach anyone to use the language, and will not give students the ability to communicate in another language. The words in songs, unfortunately, do not transfer into use." Thus it takes a lot more than just playing the song. Therefore, teachers should use songs with a particular learning purpose and activities that provide fun and entertainment. They should have an apparent reason as to why and how to use them, integrating them in a scheme of work according to the cognitive and linguistic needs of the young learners.

Similarly, according to Rouse (2005), YouTube is a free video-hosting website that permits people members of YouTube to upload and download video content freely. In this case, songs provided in YouTube have a good place because when someone searches songs in YouTube and finds it in a different case, they can choose one, two, or three of them according to what you need; official video of songs with lyrics on the screen. YouTube serves songs in many kinds of cases. Hence, we can choose the appropriate songs which we need from YouTube. The findings of this study showed that it is effective to use YouTube songs in teaching English vocabulary if parental involvement is high.
Differently, Abidin et al. (2011) conducted their research using YouTube songs as the media of vocabulary teaching. Even though their study agrees with this study that using YouTube songs is effective in teaching a new language if the parents' involvement is high, this study does not agree with Abidin's study that using YouTube songs is effective in teaching a new language if only the parents' involvement is low. This study revealed that it was effective to use YouTube songs as the vocabulary teaching media to pupils with high parents' involvement, and it was not effective to use YouTube songs as the vocabulary teaching media to pupils with low parent involvement.

On the other hand, these findings are consistent with many underlying theories about using games like flashcard games in using English vocabulary. Lewis and Bedson (2013) argue that games increase motivation and represent the primary and most important learning in young language learners. Lewis and Bedson distinguish between two basic types of games: rousers and settlers. Rousers are games that help children wake up. These are typically connected with movement. They also include games that contain the element of competition and guessing games. At the same time, settlers are games those calm children down. Typical 'settlers' include art and craft activities, games that focus on listening and writing games. There are some types of board games that can be listed in this category. At the same line, Read (2007) explains that games provide stimulation, variety, interest, and motivation; they help to promote positive attitudes to language learning. She adds that games encourage active participation and improve children's self-esteem and confidence. Games are enjoyable and funny; however, they also develop a wide range of social skills. Children have to play a game according to a particular set of rules that they have to respect and follow, they have to interact with others to reach several goals, and they have to cooperate, make compromises and learn what fair play means. Games help young children improve their memory and concentration skills. A game must be more than just entertaining. Though it is 
significant to make the lesson funny, entertaining, and motivating, a game should always be purposeful from language learning. It should have a recognizable objective, e.g., to practice a particular language structure, revise certain vocabulary areas, and improve speaking skills. This study found out that using flashcard games in using English vocabulary with only high parent's involvement.

In contrast, this study's findings do not align with Habibi's (2017) findings that show the effectiveness of using flashcards in teaching vocabulary in all cases. The researcher found out that using flashcard games was effective if parent's involvement was high, but it was not effective to use flashcard games as the vocabulary teaching media to pupils with low parent involvement.

\section{CONCLUSIONS}

This research concludes that the researcher classified the parents' involvement into high and low by distributing the researcher-made questionnaire to students' parents. The level of parental involvement in the 1st Experimental class towards teaching vocabulary using youtube songs and parental involvement in the 2nd Experimental class towards teaching vocabulary using flashcard games was high. In addition, the influence of fathers' involvement in 1 st Experimental class towards teaching vocabulary with using youtube songs was rated as low, but in 2nd Experimental class towards teaching vocabulary with using flashcard games was rated as moderate. The researcher found out that the treatment given after the pre-tests of vocabulary tests and before the post-tests of vocabulary tests was beneficial and helped the students understand vocabulary, especially with high parents' involvement. Studies on parent involvement toward their child education achievement have been conducted (Wati, 2016, Ebuta \& Ekpo, 2014, Indriati, 2016, Durisic \& Bunijevac, 2017, Dewi, 2017, Juwariyah, 2019); two of the studies is about parent's behaviour and perception on parental involvement for the success of their child success education while the rest of them are about the way of parents involving themselves in supporting their children learn English.

\section{REFERENCES}

Abidin et al. (2011). The effectiveness of using songs in youtube to improve vocabulary competence among upper secondary school studies. Theory and Practice in Language Studies, 1 (1), 1488-1496.

Bartsch, K., Horvath, K., \& Estes, D. (2003). Young children's talk about learning events. Cognitive Development, 18(2), 177193.

Dewi, S. S. (2017). Parents' involvement in childrens' english language learning. Indonesian Journal of English Teaching, 6(1), 102-122.

Durisic, M., \& Bunijevac, M. (2017). Parental involvement as an important factor for successful education. Center of Educational Policy Studies Journal, 7(3), 137-153.

Ebuta, C. N., \& Ekpo, O. (2014). Influence of parental involvement on their children's education and their academic achievement in english language. Global Journal of Educational Research, 13(1), 31-36.

Firman, \& Rahman, S. R. (2020). Pembelajaran onl,ine di tengah pandemi covid-19. Indonesian Journal of Educational Science (IJES), 2(2), 81-89.

Flecha, A. (2012). Family education improve student' $s$ academic performance: contributions from european research. Multidisciplinary Journal of Educational Research, 3(2), 301 -321.

Gikas, J., \& Grant, M. (2013). Mobile computing devices in higher education: student perspectives on learning with cellphones, smartphones \& social media. The Internet and Higher Education, 19, 18-26.

Habibi, N. (2017). The use of flashcards in improving vocabulary mastery of students with disability. INKLUSI:Journal of Disability Studies, 4(2), 197-216. https://doi.org/10.14421/ijds.040203 
Harmer, J. (2001). The practise of english language teaching (3rd ed.). Longman.

Harris, D. L. (2014). Exploring connections between parent involvement priorities, polies, programs and practices. DRUM.

Henderson, A. T., \& Redding, S. (2011). Parent leadership. In S. Redding, M. Murphy, \& P. Sheley (Eds.), Handbook on family and community engagement (pp. 105-109). Information Age.

Indriati, I. (2016). Parents' involvement in supporting their children learn english. Journal on English as a Foreign Language, $6(2)$, 145-170. https://doi.org/10.23971/jefl.v6i2.433

Juwariyah, S., Slamet, A., \& Kustiono. (2019). Analysis of parenting and involvement of parents in early childhood. Journal of Primary Education, 8(3), 364-370.

Lewis, G., \& Bedson, G. (2013). Games for children: Primary Resource Books for teachers.Oxford University Press.

Lunts, E. (2003). Parental involvement in children's education: connecting family and school by using telecommunication technologies. Meridian. 6(1).

Meara, P. (1996). The dimensions of lexical competence. In G. Brown, K. Malmkjaer \& J. Williams (Eds.), Performance and competence in second language acquisition (pp. 35-53). Cambridge.

Murphey, T. (1992). Music and song. Oxford University Press.

Pinter, A. (2006). Teaching young language learners. Oxford University Press.
Purwanto, A.,Pramono, R., Asbari, M., Santoso, P., Chi, H. C., Wijayanti, L., \& Putri, R. (2020). Studi eksploratif dampak pandemi COVID-19 terhadap proses pembelajaran online di sekolah dasar. EduPsyCouns: Journal of Education, Psychology and Counseling, 2(1), 1-12.

Read, J. (2007). Second language vocabulary assessment: current practices and new directions. International Journal of English Studies (IJES), 7(2), 105-125.

Rouse, M. (2005). YouTube, t.t.,

Schneider, J., Avis, M., \& Leighton P. (2007). Supporting children and families: Lessons from sure start for evidence-based practice in health, social care and education (pp. 261-270). Jessica Kingsley Publishers.

Sheldon, B. (2011). Cognitive-behavioural therapy: Research and practice in health and social care (2nd ed.). Routledge.

Sonntag, K. (2014). Work-family conflict, social support, and turnover intentions: a longitudinal study. Journal of Vacational Behavior, 85(1), 1-12.

Wati, S. (2016). Parental involvement and english languange teaching to young learners:parents' experience in aceh. Proceeding of International Conference on Teacher Training and Education (ICTTE), 1(1), 527-533.

Walberg, H.J. (2011).Curriculum of the home. Information Age Publishing.

Zhang, X., Friedl, M., Schaaf, C., Strahler, A., Schneider, A. (2004). The footprint of urban climates on vegetation phenology, Geophysical Research Letters, 31. 